\title{
Partners in a changing dance: embedding academic literacies in unit and course curricula
}

\author{
Linda Carol Thies \\ Deakin University, Australia \\ Viola Rosario \\ Deakin University, Australia
}

\section{Abstract}

This paper presents a two-part case study that used the seminal Lea and Street (1998) paper on academic literacies to inform ways of working collaboratively with a range of partners on embedding the development of academic literacies in course curricula. The two projects that make up the case study were funded by an Australian Government response to a greater linguistic, social and cultural diversity of students enrolling in Australian universities (Australian Commonwealth Government, 2009a). Both projects focused on the development of curricula in selected professional courses in order to increase students' awareness of the requirements of their chosen discipline, and ensure that they acquire the academic literacies needed to succeed in their area of study. What differed is the combinations of project partners and the nature of the partnerships. The case study presents the collaborative work of numerous project partners including Language and Learning Advisers (LLAs) and Subject Lecturers (SLs) in first identifying and defining academic literacies relevant to each course, and then implementing different teaching and learning practices to integrate the development of academic literacies in course curricula. Using the analogy of an ever-changing dance, the paper suggests that the degree of success and the sustainability of curriculum renewal projects depends on numerous interrelated factors, and that it may not be possible to enact academic literacy development by following set dance steps. Awareness, sensitivity and flexibility are important in bringing the dance to life.

Keywords: embedded academic literacies; curriculum development; case study; student diversity; collaboration; inclusive curriculum. 


\section{Introduction}

Much has been written over the last few decades about the need for university teaching staff and students to appreciate the difference between generic study skills and the literacy practices and professional discourse of specific disciplines (Moore and Hough, 2005; Wingate, 2006; Lillis and Scott, 2007). In a seminal paper, Lea and Street (1998) detail the differences between these two perspectives, and propose an alternative approach, attentive to academic literacies and the conflicted and contested nature of writing practices. They outline three different but overlapping approaches to student literacy development in academic settings: study skills, academic socialisation, and academic literacies. They describe the academic literacies approach as one that:

... views the institutions in which academic practices take place as constituted in, and as sites of, discourse and power. It sees the literacy demands of the curriculum as involving a variety of communicative practices, including genres, fields and disciplines. From the student point of view a dominant feature of academic literacy practices is the requirement to switch practices between one setting and another, to deploy a repertoire of linguistic practices appropriate to each setting, and to handle the social meanings and identities that each evokes (Lea and Street, 1998, p.159).

Their paper details the struggle students experience in understanding the way meaning is constructed in different disciplines, and the failure of university tutors to provide feedback on students' writing that acknowledges and helps to clarify communicative practices in specific disciplines. Explaining that students need to adapt to the literacy practices of different disciplines, they point out that these practices may be influenced by power imbalances, epistemological issues and students' identities. Lea and Street (1998) contend that students are also faced with the challenge of gaining some sense of agency or identity within their discipline, and suggest that a recognition of the impact of power imbalances on students can help change teaching and learning practice. They include a key recommendation from their original research, which is to adopt an academic literacies perspective as the focus for research aiming to interrogate teaching and learning practices and institutional policy. 
The case study presented here describes the complex ways in which Language and Learning Advisers (LLAs) partnered in two curriculum design and development projects in an ever-changing dance with subject lecturers (SLs) and a range of support teams to implement an academic literacies perspective in two curriculum design and development projects across four faculties. As lead dancers in these projects, Language and Learning Advisers likened the need to be flexible to the challenges of mastering different dance steps, to keep in step with dance partners, and to be aware of the need to change partners on the dance floor and dance styles in time with the music. As such, the projects illustrate the different and varying experiences of working in partnerships and the need to adapt and change in order to develop embedded academic literacies curricula responsive to different disciplines, teaching teams and student cohorts. An academic literacies approach can inform curriculum development, including embedded academic literacies development, but the ways in which it is enacted may vary depending on the broader political climate and more institution-specific issues, which McWilliams and Allan (2014) summarise under the headings of logistics, student demographics and discipline specific considerations. We suggest that effective curriculum development of student academic literacies also relies on the capacity of LLAs and SLs to work collaboratively.

As in a dance, curricular change offers opportunities to cross the floor to partner with different groups working on curriculum development across the university in a flexible way, and with an awareness and sensitivity to various factors, such as faculty and institutional initiatives and funding opportunities. The dance analogy helps highlight the complexity of working collaboratively with different partners in order to achieve curricular change: responding to different collaborative approaches adopted by the project partners, sharing leadership, the importance of sometimes changing partners, and recognising and acknowledging the various contributions of other dancers. The academic literacies we identified using the mapping exercise we describe varied according to the nature of the assessment task and the discipline; just as in a dance, participants offer different interpretations of prescribed dances. We suggest that, just as dancers need to sustain energy and enthusiasm, effective curricular change requires collaboration and commitment over a lengthy period of time.

\section{Background to the two projects}


While our partners in the dance sometimes changed, one constant through both projects was our partnership with students. The two projects that make up the case study were initiated in response to a greater diversity of students entering Australian universities as a result of the globalisation of higher education, an increase in entry pathways and the Australian Government's policy of widening access (Australian Commonwealth Government, 2009b; Varghese, 2013; Norton 2016). They were funded through the High Education Participation and Partnerships Program (HEPPP), an Australian Government initiative introduced with the specific aim of increasing the success of students of lowsocioeconomic status backgrounds (Australian Commonwealth Government, 2009b). The literature outlines the needs of students from diverse backgrounds, including lower stocks of social and cultural capital, lower levels of previous education attainment, lower aspirations and levels of competence in English language and a higher need for personal and academic support (Bourdieu, 1986; James, 2002; Young, 2004; Coates and Krause, 2005; James, 2007; Priest, 2009; Hunter, 2019). The Lea and Street (1998) paper provided the rationale and academic literacies theory underpinning these projects. However, while the introduction of HEPPP initiatives acknowledged the likelihood that students from diverse backgrounds would have considerably higher needs, academic literacies theory represents a movement away from a deficit model, which focuses on teaching instrumental skills. The main focus in these projects was therefore on the socialisation of all students into the discourses of their disciplines and - more broadly into academia. We stepped gently to invite all students to the dance.

This diversity of students' cultural and language backgrounds, socioeconomic status, age, and professional aspirations prompted a greater focus on student needs and the development of curricula that respond to those needs. The key response to student diversity, which could be implemented at an institutional level, involved better integration or embedding of academic literacies within course curricula. The academic literacies projects presented here demonstrate the tension between funding, which highlights the needs of certain student cohorts, and the aim of developing curricula that respond to the learning needs of all students. The overall objective of the projects was to take an inclusive approach to ensure that all students, local or international, irrespective of their stock of cultural capital, were empowered to understand the underpinning requirements of university assignments, pass assessment tasks, successfully complete their course and 
graduate ready to enter the world of work in their chosen profession. As such, the project briefs were also seen as contributing to a university-wide process of curricular renewal.

The projects were conducted at an Australian university with approximately 44,000 students enrolled in 2012, across four campuses, three of which are in regional areas, and approximately $28 \%$ of students studying wholly online (Deakin University, 2013). Course enrolment increased to approximately 67,500 in 2018 and, as such, the diversity within the student cohort also increased (Deakin University, 2018). At the commencement of the first project the University was engaged in a course enhancement process, which included a review of unit and course learning outcomes, and how these contribute to students' achievement of graduate attributes. All faculties conducted some professional development sessions as part of this review and the enhancement process was driven by Faculty Associate Deans, Teaching and Learning. This gave us an opportunity to partner with a range of colleagues working on curriculum development. The first academic literacies project involved close collaborations in four key undergraduate courses: Early Childhood Education, Social Work, Information Technology and Health, and was overseen by one of the Faculty Associate Deans, Teaching and Learning. The second project, which was a new iteration on the original theme, focused on Management units in Business and Law, and the continuing work in Early Childhood Education. Both projects took an inclusive approach to embedding academic literacies in course curricula in order to ensure the development of the skills and literacies students require to achieve academic success.

\section{Embedding academic literacies in course curricula}

The literature describes various approaches to embedding the development of academic literacies in curricula (Chanock et al., 2012; Johnson et al., 2015). This type of curricular enhancement has been planned and delivered in a variety of different ways in higher education institutions over at least the last two decades (Maldoni and Lear, 2016). A common initial step involves defining academic literacies and constructing academic literacies frameworks. These frameworks may include mapping the academic literacies required to successfully complete assessment tasks in one unit of study. However, curriculum development may also take a course level focus, such as including online modules in a course site or in a specific core unit that all students enrolled in a course are required to complete (Thies et al., 2014; Minogue et al., 2018). A case study presented by 
Johnson et al. (2015) describes a university-wide academic literacies framework for the development of students' communication skills across different courses. The academic literacies identified and mapped using specific frameworks will therefore differ. As with the variety of 'dances' and different interpretive dance styles, academic literacies curricula may have very different content and can be presented and delivered in a variety of ways.

Some frameworks have been developed, which identify what could be termed 'key academic literacies' (Harper, 2011; McWilliams and Allan 2014). McWilliams and Allan (2014) identify academic literacies such as 'critical thinking, database searching, familiarity with academic conventions such as referencing, use of formal register and the ability to manipulate a range of genres' (p.1). Another definition by Chanock et al. (2012) is that academic literacies are seen as 'oral, social and electronic ways of dealing with knowledge as well as print literacies' (p.1). The focus of both projects presented here was on the academic literacies needed for students to succeed in assessment tasks. The diagram below (Figure 1) was used to demonstrate the link between academic skills and literacies that need to be developed through assessment tasks in the context of the university-wide curricular renewal process, which focused on graduate learning outcomes (Jolly, 2001).

Figure 1. University curriculum renewal process (based on Jolly, 2001). THE PROCESS FOR DEVELOPING ACADEMIC SKILLS AND LITERACIES IN YOUR COURSE

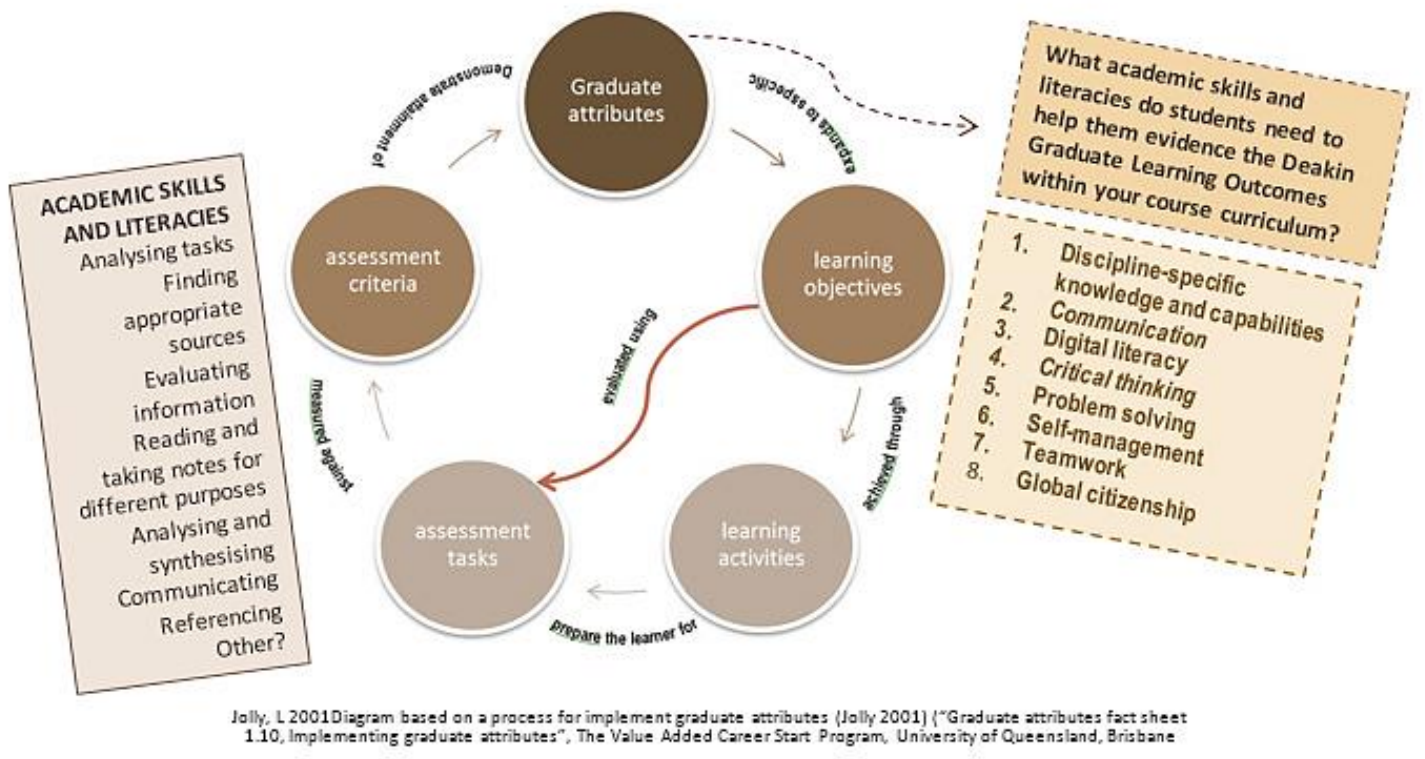


The project also drew on the academic literacy development framework put forward by Harper (2011), which highlights eight facets of academic literacies relevant to the completion of assessment tasks (reading, recording, reviewing, responding, researching, relating, reporting and referencing), and five developmental levels that describe increasing competence through iterative development across the course. The project participants had to 'keep in step' with the chosen dance style by discussing and agreeing on which academic literacies were most relevant for inclusion in unit or course curricula, and how students could demonstrate their capabilities or competence in these literacies.

Different understandings of the nature of academic literacies add to the complexity of attempts to incorporate the explicit teaching of academic literacies in the delivery of units. In introducing both projects to teaching teams, the LLAs presented the aim of embedding academic literacy development in course curricula as providing learning experiences that build students' understanding of different literacy practices, their ability to switch to different ways of thinking and writing in different disciplines, and awareness of the varying ways that they are developing as learners. During the initial project planning stage, LLAs suggested that academic literacies theory could be used to inform both the design of the curriculum and the approaches to teaching. Both projects focused on developing a shared understanding of academic literacies theory, embedded academic literacies curricula, and how project members could contribute to curriculum development. Gustafsson et al. (2011) describe this shared understanding of contributions to curriculum development as bringing together different pedagogical knowledge by integrating content and language. They explain the content knowledge of subject specialists as including the discipline's epistemology, conventions, values and assumptions, while LLAs have a knowledge of applied linguistics and can talk about the discourse of the subject in a way that clarifies its use for students. Therefore, recognition of these varying contributions meant that while LLAs often adopted the role of lead dancer, our steps had to be quite delicate, and we often deferred to SLs and course coordinators in the decision making process.

The use of the term 'embedded' in relation to curriculum development can be quite contentious in that it is seen as suggesting that there are certain literacies that are external to more valued discipline knowledge. This reflects the contested view that teaching generic academic skills or study skills using what has been described as a 'bolted on' approach will be sufficient for students to learn the literacy practices of their discipline (Wingate, 
2006). The limitations of this 'bolted-on' approach are well documented, and include students' perception that additional sessions offered are remedial and/or irrelevant to learning in their discipline (Durkin and Main, 2002; Lea and Street, 2006; Thies, 2012; Cairns et al., 2018). The development of a shared understanding between project partners included recognition of the value of embedding literacies development in unit and courses curricula rather than expecting students to attend additional generic academic skills workshops. There is also a need to embed academic literacies into the curricula in a seamless way so that students perceive them as fundamental elements of discourse in their discipline. However, while students may perceive these academic literacies as an integral part of their developing knowledge, they also need to take a broader perspective of the context of their performance, to develop a metacognitive approach to their learning and to reflect on their achievement of course learning outcomes. In the projects presented here this was achieved through providing students with a self-reflective tool to encourage reflection on the development of their own academic literacies over at least one year of their study.

Delivery of curricula can include the traditional methods of lectures and tutorials, interactive online learning activities and/or team teaching by literacy and discipline specialists. The projects presented here aimed for a flexible response to each disciplinary context and adopted a variety of different approaches to delivery. These approaches were informed by assessment of student needs, the academic literacies mapped by individual project teams, the unique characteristics of the discourse community and in some instances the logistics and timing of delivery. There was a strong focus on inclusive online development in the learning management system. The Project Coordinators used academic literacies theory as the starting point for course or unit team discussion. Figure 2 was presented to project partners during professional development sessions and as an online resource. It shows how the academic literacies model builds on older models for a more encompassing understanding of student learning (Lea and Street, 1998).

Figure 2. From study skills to academic literacies (Lea and Street, 1998, p.172). 


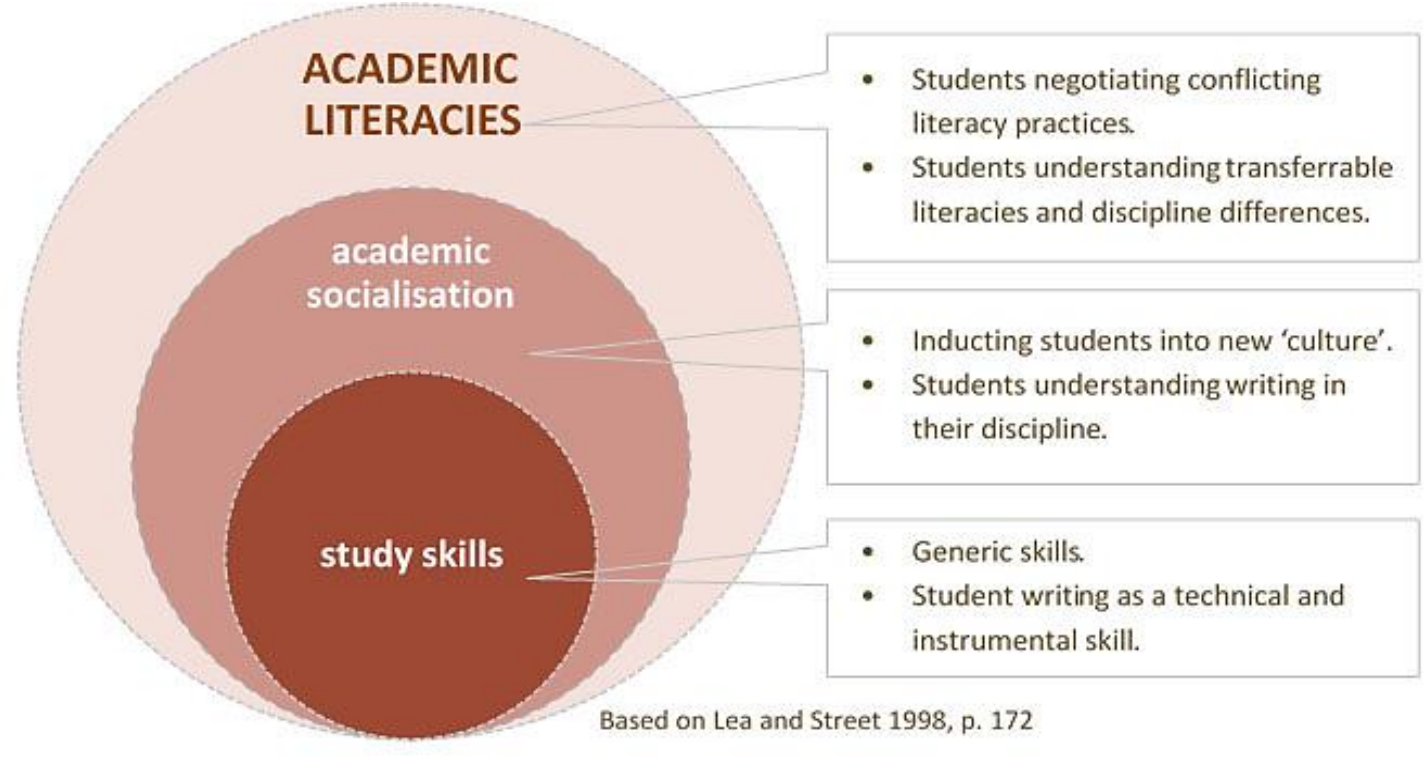

\section{Curricular renewal: barriers and facilitators}

While much research has been done using an academic literacies perspective since the Lea and Street (1998) paper was published, a critique of the theory as originally presented is that it did not include any teaching design framework or detailed pedagogy (Lillis, 2003; Wingate and Tribble, 2012). This suggests that there is much to learn about how curriculum design can support students to move towards communicating effectively within their discipline and/or understanding 'the hidden rules of the game'. There are many explanations provided as to why an embedded approach to academic literacies curriculum development has not been adopted more widely (Moore and Hough, 2005; Jones, 2008). Jones (2008) highlights barriers to curriculum development, including the complexity of defining academic skills and literacies, which are not necessarily observable or measurable, and the fact that academics may therefore not understand the nature of these literacies and may lack experience and confidence in teaching them. Lea (2004) does suggest principles of course design based on the academic literacies model and a list of limitations of planning and implementation, which are illustrated using one case study of an online course for postgraduate students. However, again, this does not provide clear links between academic literacies and teaching and learning activities in the mainstream higher education classroom. In likening this process to a dance, it would seem that there is no single dance style or set of steps that guarantee the success of such course design. In developing embedded academic literacies curricula, project partners need to adapt to the 
circumstances within their institution, adopt processes, and establish partnerships that will best progress project aims.

In the introduction to a book entitled Working with academic literacies: case studies towards transformative practice the editors (Lillis et al., 2016, p.3) suggest that the series of case studies and critical reviews included in the book provide some answers to questions such as 'How do we work with an academic literacies approach' and 'How does the transformative approach look in practice?'. They argue that one rationale for the publication of these articles was the existence of a gap between the understanding of researchers and practitioners regarding responses to these questions. The overall message of this book is that these case studies contribute to an understanding of:

... contemporary approaches to language and literacy, in particular, how to design policy, curriculum, assessment and pedagogy which engage with a commitment to 'transformation' - rather than solely induction or reproduction - and indeed, to examining what we understand by 'transformation' in contemporary higher education (p.5).

Reflection on the two projects presented here does provide some insights into the key areas detailed in this text (Lillis et al., 2016), such as teaching practices, pedagogies, resources and responses to institutional policies.

A number of different interrelated factors are needed in order to facilitate curricular renewal that incorporates students' development of academic literacies. While it has been suggested that a whole-of-institution approach and top-down support are essential if curricular change is to be sustained, bottom-up input and involvement is also key to innovative curriculum renewal and enactment (Kift, 2009; Thies, 2014; McWilliams and Allan, 2014). As such, collaborative curriculum development must be supported by policy and formal structures that promote engagement at multiple levels within the university, as well as ways of working across faculty, department and professional area boundaries. These suggested ways of working imply the need for collaboration between various practitioners, and much of the literature focuses on the importance of team-based approaches to curriculum design (Healey et al., 2013; Burrell et al., 2015; Minogue et al., 2018). 
As with any dance performance, all partners in the routine need to be confident that they are seen as key contributors and that their contribution is recognised and valued. Murray and Nallaya (2016) contend that a systematic embedding process relies on collaboration between language and learning specialists and academic staff, while Goldingay et al. (2016) emphasise the importance of team members being involved in a structured process of reflective practice, which could contribute to an ongoing action research cycle, including planning, acting, observing and reflecting. A shared understanding, including a shared vocabulary, has already been highlighted as one of the key components of a collaborative approach, and this is best achieved by the provision of professional development programmes and sufficient time for staff to be fully engaged (Thies, 2016; Goldingay et al. 2016). McWilliams and Allan (2014) emphasise the importance of a student-centred or autonomous learner focus in order to promote students' self-efficacy and an ability to think critically about their learning, both in terms of discipline content and an ability to communicate their knowledge. Finally, while the mapping of academic literacies across units is seen as a first stage in developing curricula (Willison and O'Regan, 2007; Willison et al., 2010; Harper, 2011), Bath et al. (2007) argue that a curriculum development process must include ongoing review, change and renewal. Drawing on the dance metaphor, this argument for change and renewal suggests the need for a number of lead dancers, and an additional need for these leaders to sustain energy levels and enthusiasm. While the interrelated factors outlined above are not definitive, they do provide an indication of the complexity of developing curricula in an integrated and incremental way.

\section{Project 1: Developing academic literacies curricula}

The overall aim of the first project, which spanned a three-year period, was to develop embedded academic literacies curricula in units across a number of courses in order to increase student success rates. Funding was allocated to teams in the selected undergraduate courses, and a group of core units in the Faculty of Health. Ethics approval was granted for collaborative research evaluation. This included reflections by the LLAs coordinating the project as well as separate ethics approval for each course team. There was also funding for a part-time research assistant to contribute to evaluation of the 
project. The project was coordinated by two LLAs, who initially worked with Associate Deans, Teaching and Learning, and course teams to identify which subjects to focus on, and then defined a theoretical basis, provided practical frameworks, developed curricula and planned project evaluation. The project began with a full day seminar introducing the project, with two additional full day seminars for the different course teams to share project outcomes. There was a working group for each subject or series of subjects with one LLA coordinator in each group. A number of other LLAs were co-opted to support resource development.

As there was some funding for course team involvement and the project was being led by one of the Faculty Associate Deans, Teaching and Learning, the nominated course teams were keen to capitalise on the opportunity to review their curricula. The introductory whole day seminar was an excellent networking opportunity, and provided teams with the opportunity to make decisions regarding how they would begin the collaborative curriculum development process. This involved setting up meeting times to progress the mapping of academic literacies of assessment tasks in specific units. The starting point for each working group was to identify the key academic literacies needed to successfully complete assessment tasks. The framework used for this mapping exercise also required identification of those literacies already being supported or scaffolded, and those that were not taught or included in the curriculum. The aim was to create curricula that best suited the discipline and the teaching team. As could be predicted, each working group responded differently, based on a range of different issues, such as the logistics of delivery of the subject, assessment of student need, discipline considerations, and recommendations of subject review processes. Figures 3 was used to begin and progress the mapping of academic literacies and support the development of learning resources to scaffold assessment tasks in specific units.

Figure 3. Facets of academic literacy (based on Harper, 2011). 


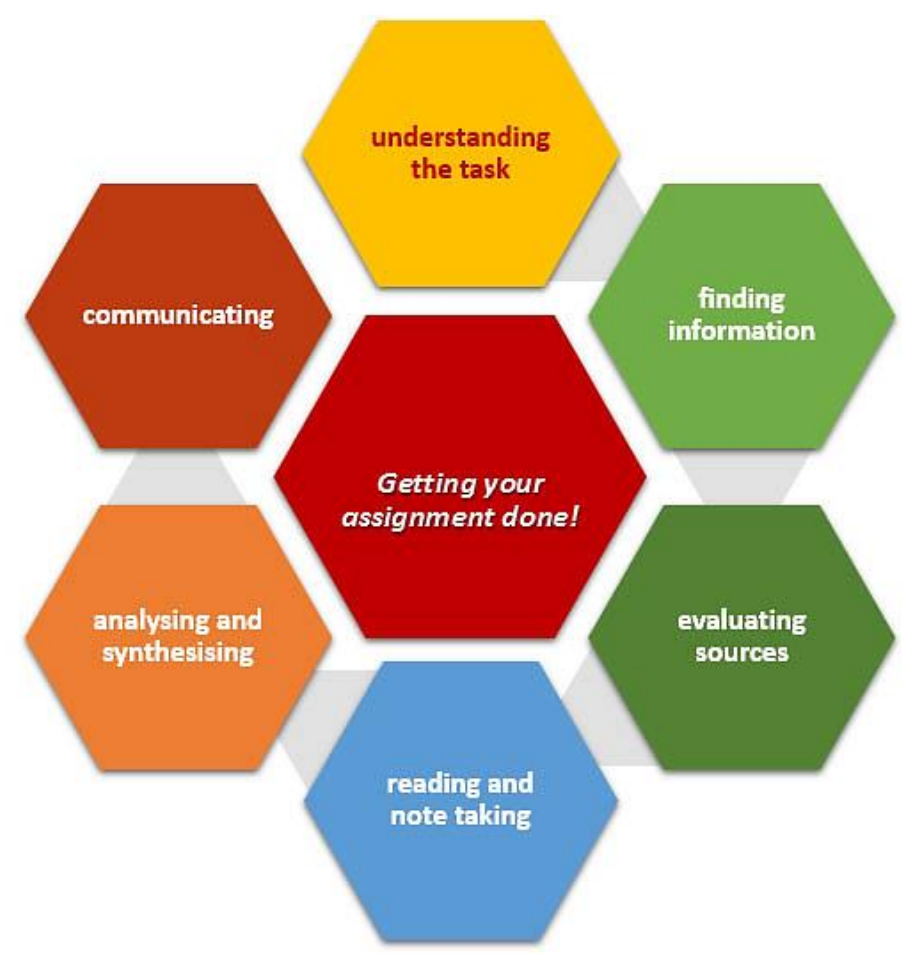

Because the focus was on resource development to support student success, LLAs revised the terminology used in the academic literacy framework proposed by Harper (2011) to more closely align with existing resources available for students to create the 'facets of academic literacies'. While terms like 'finding information' and 'reading and note taking' could be seen simply as study skills, taking an academic literacies approach in this project, LLAs and SLs worked together to redefine the nature of these core skills in the context of assessment tasks and course learning outcomes and developed online resources specific to different units in different disciplines (Figure 4).

Figure 4. Academic literacy resources in the online environment. 

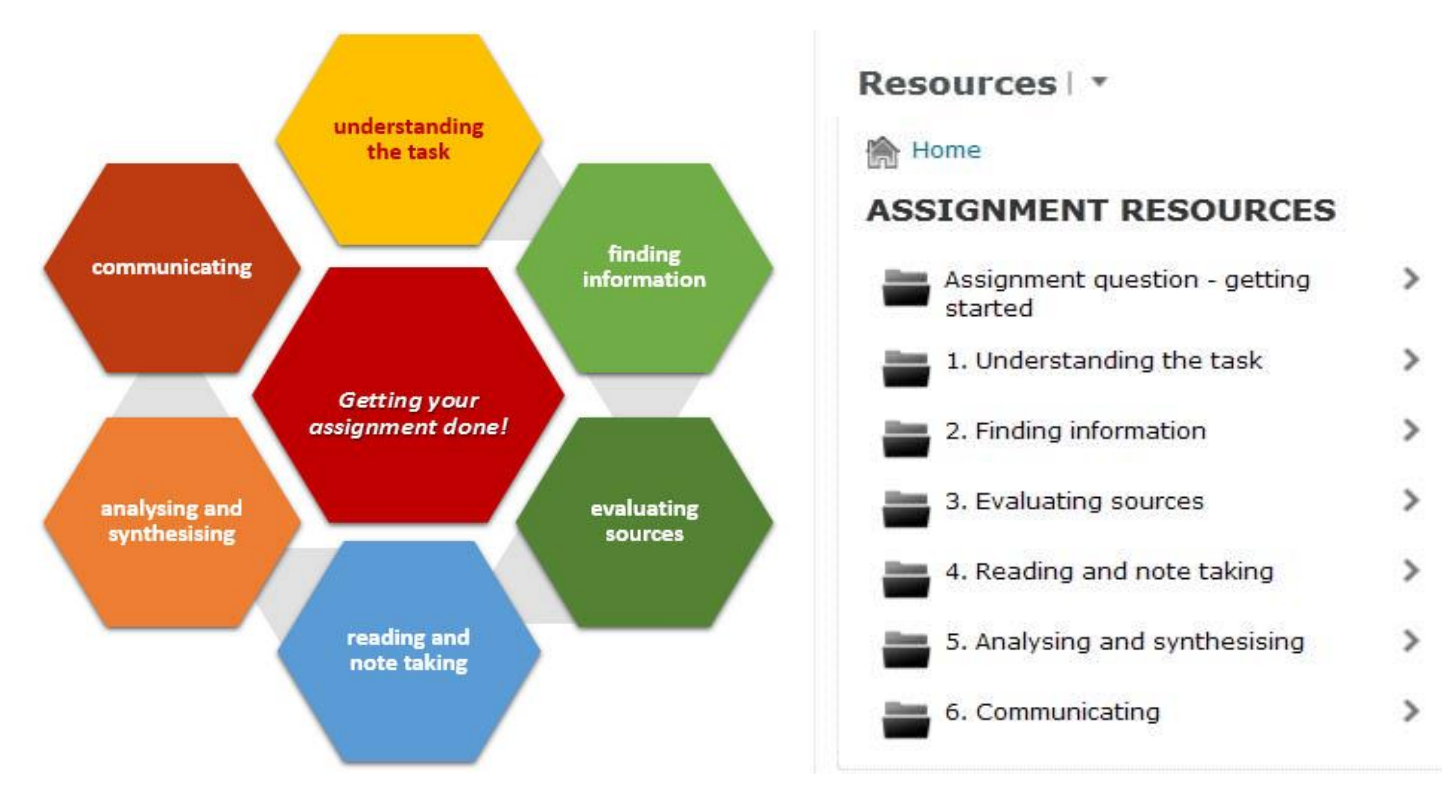

The focus across the courses was on developing shared understandings between SLs and LLAs about the nature of the academic literacies that students were expected to develop in each assessment task, beyond basic study skills, in order to develop an awareness of the specific literacy practices involved and scaffold the socialisation of students into their discipline.

This led to a collaborative identification of a second layer of the metacognitive skills required in academic engagement, including self-management and reflection. Figure 5 illustrates how additional literacies (facets) were identified and introduced into the mapping exercise during discussions with teaching teams. Thus, the model we used expanded to invite reflection on other skills implicit in assessment tasks, and led to an awareness of different ways in which reflection is enacted in disciplines as varied as Information Technology, Early Childhood Education and Social Work, to respond to external professional and disciplinary requirements that pull on and shape course curricula.

Figure 5. Broader facets of academic literacy. 


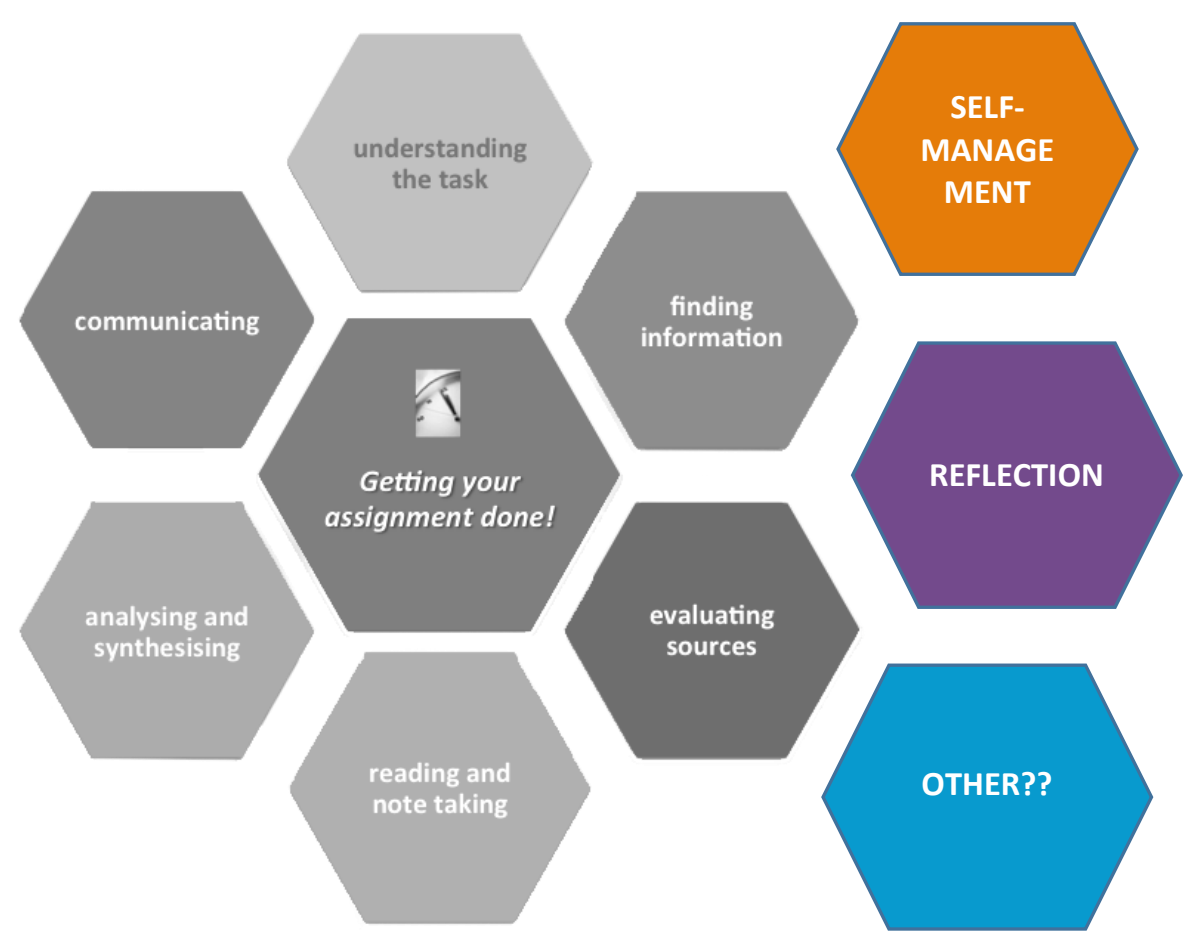

It was important to keep in step with our partners. To progress the project, regular working group meetings were planned and chaired by the LLA Project Coordinators, and as the programme was being enacted across four different campuses these were often video link or Skype meetings. These meetings, the additional showcasing of resources at course team meetings, and joint conference presentations, provided an incentive for continuing collaboration. The Project Coordinators sought to include the 'student voice' in resources such as video clips with short accounts of students' experiences of studying in the different disciplines. Students involved in peer mentoring programmes were also invited to attend PD sessions, and to contribute to presentations as members of a panel. As the project progressed the research assistant met regularly with the LLA Project Coordinators, and also contacted all team members individually so that they could have input into the research evaluation, which also provided support for ongoing collaboration. Meeting outcomes and actions were shared with all working group members. In this first project, LLAs and course teams worked in tight partnerships with SLs, and also invited students into the academic dance. Funding changes in the second project led to new partnerships and what could be described as a widening of the dance.

\section{Project 2: Inclusive education and staff capacity building}


The Inclusive Curriculum and Capacity Building Project was a shorter reprise of the original three-year project and had a different momentum. It was also government funded through HEPPP, but was conducted over a single year. While this project built on the recommendations from Project 1, there was a greater emphasis on staff capacity building, with a focus on inclusive education and the embedding of essential academic and digital literacies and career development into undergraduate curricula. A key aim was sustainability beyond the life of the project. The project was managed by the Equity and Diversity area of the University, and project partners included Language and Learning Advisers (LLAs), Liaison Librarians, Careers Advisers, the Institute of Koorie Education, an inclusive curriculum design practitioner as well as co-opted members of academic teaching teams. The project brought together some of the partners from earlier HEPPP projects, and while staff who had been involved in Project 1 saw this as a continuation of their previous work, there was a need to initiate different ways of engaging academic teaching teams, some of whom were new to the project.

Much of the embedded academic literacies work in this project was done in collaboration with SLs in the Faculty of Business and Law. Working with units in the School of Management, the project team reviewed assessment tasks and marking criteria in a first year and second year unit to ensure clarity and accessibility. A range of customised online learning resources, which included models of writing and teaching resources for tutorials, were then created in order to scaffold assessment tasks. Each unit at this university has an online site and the sites for these two Management units included resources that focused on the stages or facets of academic writing. The Management lecturers, Liaison Librarians (LLs) and LLAs presented jointly in at least two lectures and LLAs offered further feedback on assignment writing in 'Drop in with a draft' sessions. LLAs and LLS also participated in unit online discussion boards. Additional sessions on analysing the question and structuring the assignments were offered to students studying totally online using Blackboard Collaborate. As these curricular changes were being made across two years of a course, there was a need to factor in students' development of academic literacies over a two-year period, and to sequence the resources to support this development. The Early Childhood Education (ECE) team continued to develop a course site - 'The Early Childhood Education Learning Hub', which presented a number of different modules on specific academic literacies. All staff and students studying ECE had access to this site and links to these resources were included in individual ECE unit sites. 
The final module was on reflective learning, and included a self-reflection tool on students' development of academic literacies, which students were required to complete at different times during their study.

Professional development was a key feature of this second project, with the overarching aim being for staff to gain an understanding of the principles of inclusive education. Inclusive education aligns with good teaching practice and refers to curriculum design that incorporates multiple means of representation, expression and action and student engagement (Morgan and Houghton, 2011). This approach takes into account student diversity and involves engaging students in learning that is relevant and accessible (Gale, 2010). One component of this professional development was for staff to gain a shared understanding of how a focus on academic literacies in curriculum development could contribute to inclusive education. Face-to-face professional development sessions involved presentations from Project 1 teams in order to showcase academic literacies curriculum development, and these sessions involved participation by both ongoing and sessional staff teaching in the targeted units. Professional development videos were created with lecturers in Management for use at the Faculty level and to highlight the work of LLAs across the University. In addition, the inclusive design practitioner offered group PD sessions and individual support for curriculum development.

The widening of the dance to include additional partners in Project 2 meant that a collaborative approach between all members of the working group was more complicated. Both the manager and lead for this project were from the University's Equity and Diversity unit. While this structure contributed to information sharing across different HEPPP projects, the inclusion of what seemed to be an intermediary or additional planning process made collaboration more complex. There was a need for meetings of the larger project team and smaller working groups, which meant that the workload for all team members was increased, and the shortened length of this project often meant that the time period to plan and implement curricula was unrealistic. While the smaller working groups continued to collaborate, there was insufficient time to develop more complex structures to support collaboration across the project team. To call on the dance metaphor, the dancers continued the dance, but needed new choreography in order to dance with the larger team. 
Despite the challenges described above, the project achieved its stated aims, which were to build staff capacity to adopt sustainable approaches to embedding academic literacies, career development and principles of inclusive education in course design. The project team was 'Highly Commended' in the Vice Chancellor's Award for Teaching Excellence recognising the wide range of partners involved, the collaborative nature of the project and the project's impact on teaching and learning at the university level. The LLAs and SLS produced a joint presentation at national conferences (Thies et al., 2013a; Thies et al., 2013b), as well as presentations at the University's Teaching and Learning conferences.

\section{Lessons learnt: what remains when the dance is done?}

The evaluation data from both the projects is not presented here, but can be found in previous papers (Thies et al., 2014; Thies, 2016). The data supports a conclusion that students perceived these approaches as having enhanced their learning and contributed to their understanding of the ways to research, think, write, question and practise in their discipline. Feedback from the staff confirmed that they believed that the collaborative approach and opportunity to reflect had enriched curricula and teaching practice across the University in a number of different ways. Some project initiatives could be said to contribute to deep student learning or a movement towards a transformative approach, including incorporating the student voice into all professional development sessions, and the inclusion of different models of students' self-reflection on the development of their academic literacies. The experience of the project partners also confirmed that university staff who contribute to course development should be aware of possible barriers and facilitators to such curricular change as previously outlined, and make strategic choices depending on national political decisions, availability of funding and the current policy directions of their individual higher education institution. For these reasons, the ideal of a 'one size fits all' model may be elusive: instead, practitioners will need to demonstrate a willingness to be flexible and innovative in order to achieve curricular change. As it is now several years since the completion of these projects it is timely to ask 'What is the legacy of these projects?' and 'In what way have these projects contributed to future directions?'

Like dancers in a constantly moving dance, our roles as LLAs in the two projects that make up this case study required an awareness of the environment and sensitivity to changing project partners. Our experiences highlight the importance of simultaneously 
being aware of the broader political context, working within the scope of university initiatives and focusing on the specific learning and teaching needs of students and staff in different disciplines. While the funding for these projects came from HEPPP and was aimed at social inclusion, the University was in the process of a major course enhancement process. We took advantage of this synergy to link academic literacy development to the implementation of graduate attributes in course curricula, the processes of Australian Qualifications Framework (AQF) accreditation and course reaccreditation, as well as the academic promotion process. As these were the key factors driving a focus on improved teaching and learning approaches, this broader approach opened up the space for us to offer new perspectives. The use of an academic literacies approach ensured that our focus was squarely on improving learning and teaching outcomes and on the many-faceted needs of all learners.

As LLAs we took the view that learning from one team in one discipline could be shared and adapted to different units and courses in a recursive process, and could have an impact at the institutional level. A dedicated conference strand in the University Teaching and Learning Conference 2012 contributed to shared learning from the first project, as did research publications jointly authored by LLAs and SLs. 'The Guide to developing academic literacies in your course curriculum' created as part of the staff capacity building imperative of the second project is currently being redeveloped in a university-wide professional development site on 'Curriculum development for teaching staff'. The 'Facets of academic literacy' (Figures 3 and 5) are included in 'The Guide'.

There has been a wider impact of these projects than we expected when we first commenced the dance. The reusability of learning objects created as part of the projects is an essential factor. To some extent, the resources developed as part of the projects have 'gone wild'. A video about the academic skills and literacies needed for assessment tasks has been used in several units; the resources built in the Management unit sites have been adapted by SLs in other units in the Faculty of Business and Law; the videos developed to support the use of the ePortfolio tool for reflection in the School of IT project have been used at the institutional level to support reflection in several disciplines. Although the course sites developed for the Bachelor of Social Work had become out of date as previous unit chairs involved in the project have left the University, there is an intention to reuse the videos presenting student voices in a future development of the 
course site. Similarly, a tool for students' self-reflection on their development of academic literacies originally presented on the Bachelor of Early Childhood Education course site has been re-developed for use in other courses.

While this awareness of the larger picture helped ensure that the projects contributed to curricular renewal, we are aware of the way in which changes in staff can impact on sustainability. A number of outcomes have been sustained, but there is a need to qualify the value and likelihood of ongoing sustainability of some of these outcomes. For example, different pedagogical knowledge shared by collaborating teams is sometimes lost through staff changes. Continuing use of online learning resources can also place a burden on LLAs and SLs to review and revise. It is encouraging to note that structural changes within the institution mean that LLAs have now taken on faculty liaison roles, working more closely with SLs, as a way of making a broader contribution to the strategic goals of the University. As part of this wider approach, a new 'Transition Toolkit' project that provides exemplars of resources, such as learning activities, which teaching teams can draw upon in scaffolding the development of academic literacies at the first-year level, will draw on some of the work done in the two projects. There may be scope for further development of resources, like the tools to support self-reflection, to contribute to students' reflection on achievement of course learning outcomes (CLOs). As initially suggested in this paper, the leaders of an academic literacies approach need to be innovative in seeking ways to sustain these outcomes. For example, as the Federal Government moves away from supporting low SES background students, HEPPP funding will not be available, so one imperative will be to explore other funding sources and/or to identify other ways of prioritising time for collaborative curriculum development.

\section{Conclusion}

The twin projects that make up this case study illustrate some of the enabling factors for using an academic literacies perspective to help drive curricular change. The success of most components of the projects (and failure of some) was largely dependent on the level of collaboration between different project partners, and this collaboration aimed to foster a shared understanding of language, theoretical frameworks, and pedagogical approaches. Comparing some aspects of the collaborative approach in this case study to a dance has helped us recognise the complexity of the performance as well as the facilitators and 
barriers to curricular change. The case study also demonstrates how academic literacies theory can be used as the rationale for curricular design and teaching practice. Adopting different approaches and mapping frameworks to identify, define and explain the academic literacies privileged in the discourse of specific disciplines represents, a movement away from the basic dance pattern of a focus on generic academic skills.

The major objective of raising student awareness of the academic requirements within their discipline area, as well as in the broader university context, was achieved through adopting curricula that best suited the discipline and teaching team. This included the development of online resources and learning activities for students, team teaching by LLAs and SLs, and resources and professional development sessions with a focus on staff capacity building. A movement towards a transformative approach - where students start to understand the 'hidden rules of the game' and explore issues of power and identity was more challenging.

The projects contribute to an understanding of different ways of approaching curriculum design using an academic literacies perspective. However, the manner in which this curricular change might be enacted will not only be contingent on policy directions at the national and institutional level, but even more so on priorities at the faculty or department level of individual higher education institutions. A spectacular dance performance is contingent on the flexibility of the dancers - sometimes dancing in sync and sometimes individually, sometimes taking the lead and sometimes following, able to perform different dance styles and, most importantly, sustaining high energy levels until the curtain call. Similarly, the movement towards academic literacies' best practice will require enthusiasm, commitment, flexibility, and an ability to keep in tune with broader political imperatives, while working collaboratively with a range of key players across the university to keep pace with the needs of new waves of students.

\section{References}

Australian Commonwealth Government. (2009a) Transforming Australia's Higher Education System. Canberra: Commonwealth of Australia. Available at: http://www.deewr.gov.au/HigherEducation/Documents/PDF/Additional\%20Report\% 
20-\%20Transforming\%20Aus\%20Higher\%20ED webaw.pdf (Accessed: 20 February 2010).

Australian Commonwealth Government. (2009b) Speech by Lisa Paul, 'Transforming Australia's Higher Education System'. Canberra: Commonwealth of Australia. Available at: https://docs.education.gov.au/documents/transforming-australiaseducation-system-speech-lisa-paul-november-2009 (Accessed: 1 June 2015).

Bath, D. Smith, C. Stein S. and Swann, R. (2007) 'Beyond mapping and embedding graduate attributes: bringing together quality assurance and action learning to create a validated and living curriculum', Higher Education Research and Development, 23(3), pp.313-328. Available at: https://doi.org/10.1080/0729436042000235427 (Accessed: 1 May 2019).

Bourdieu, P. (1986) 'The forms of capital', in Richardson, J.G. (ed.), Handbook of theory and research for the sociology of education (trans. Richard Nice). New York: Greenwood Press.

Burrell, A., Cavanagh, M., Young, S. and Carter, H. (2015) 'Team-based curriculum design as an agent of change', Teaching in Higher Education, 20(8), pp.753-766. Available at: http://dx.doi.org/10.1080/13562517.2015.1085856 (Accessed: 1 May 2019).

Cairns, J. Hervey, T. and Johnson, O. (2018) 'Neither 'bolt-on' nor 'built-in': benefits and challenges of developing an integrated skills curriculum through a partnership model', Journal of Learning Development in Higher Education, Issue 13, April, Available at: https://journal.aldinhe.ac.uk/index.php/jldhe/article/view/435 (Accessed: 30 May 2019).

Chanock, K., Horton, C., Reedman, M. and Stephenson, B. (2012) 'Collaborating to embed academic literacies and personal support in first year discipline subjects', Journal of University Teaching and Learning Practice, 9(3), Available at: http://ro.uow.edu.au/jutlp/vol9/iss3/3 (Accessed: 9 May 2016). 
Coates, H. and Krause K. L. (2005) 'Investigating ten years of equity policy in Australian higher education', Journal of Higher Education Policy and Management, 27(1), pp.35-47.

Deakin University. (2013) Annual Report. Available at: https://www.deakin.edu.au/aboutdeakin/strategic-direction? ga=2.132708297.673047362.15709405521750931484.1561700617 (Accessed: 20 May 2016).

Deakin University. (2018) Annual Report. Available at: https://www.deakin.edu.au/aboutdeakin/strategic-direction? ga=2.132708297.673047362.15709405521750931484.1561700617 (Accessed: 1 May 2019).

Durkin, K. and Main, A. (2002) 'Discipline-based study skills support for first year undergraduate students', Active Learning in Higher Education, 3(24) pp.24-39. Available at: https://doi.org/10.1177\%2F1469787402003001003 (Accessed: 1 May 2019).

Goldingay, S., Hitch, D., Carrington, A. and Rosario, V. (2016) 'Transforming roles to support student development of academic literacies: a reflection on one team's experience', Reflective Practice: International and Multidisciplinary Perspectives, 17(3). Available at https://doi.org/10.1080/14623943.2016.1164682 (Accessed: 1 May 2016).

Gustafsson, M., Eriksson, A., Raisanen, C., Stenberg, A., Jacobs, C., Wright, J., WyrleyBirch, B. and Winberg, C. (2011) 'Collaborating for content and language integrated learning: The situated character of faculty collaboration and student learning', Across the Disciplines, 8(3). http://wac.colostate.edu/atd/clil/gustafssonetal.cfm (Accessed: 26 May 2016).

Harper, R. (2011) Academic literacy development framework. University of Canberra: Academic Skills Centre.

Healey, M., Bradford, M., Roberts, C. and Knight, Y. (2013) 'Collaborative discipline-based curriculum change: applying Change Academy processes at department level', 
International Journal for Academic Development, 18(1), pp.31-44. Available at: https://doi.org/10.1080/1360144X.2011.628394 (Accessed: 10 May 2016).

Hunter, F. (2019) 'Government raises concerns over foreign uni students English skills', Sydney Morning Herald, 10 May.

James, R. (2002) 'Socioeconomic background and higher education participation: An analysis', Department of Education, Science and Training: Canberra. Available at: http://www.cshe.unimelb.edu.au/research/equity/docs/eip02 5.pdf (Accessed: 1 May 2016).

James, R. (2007) 'Social equity in a mass, globalised higher education environment: The unresolved issue of widening access to university', Series 2007. Available at http://www.cshe.unimelb.edu (Accessed: 16 January 2016).

Johnson, S., Veitch, S. and Dewiyanti, S. (2015) 'A framework to embed communication skills across the curriculum: A design-based research approach', Journal of University Teaching and Learning Practice, 12(4). Available at: http://ro.uow.edu.au/jutlp/vol12/iss4/6 (Accessed: 16 January 2016).

Jolly, L. (2001) 'Implementing graduate attributes, Graduate attributes fact sheet 1.10', The Value Added Career Start Program. University of Queensland, Brisbane. Available at: http://www.vacs.uq.edu.au/final/1 10.pdf (Accessed: 4 August, 2011).

Jones, J. (2008) 'Generic Attributes: an agenda for reform or control', Changing Identities. Available at: https://learning.uow.edu.au/LAS2001/selected/jones 2.pdf (Accessed: 1 May 2016).

Kift, S. (2009). 'Articulating a transition pedagogy to scaffold and to enhance the first year student learning experience in Australian higher education. Final report for ALTC Senior Fellowship Program'. ALTC Resources. Available at: http://www.altc.edu.au/resources-first-year-experience-kift-2009 (Accessed: 16 January 2016). 
Lea, M. and Street B. (1998) 'Student writing in higher education: An academic literacies approach', Studies in Higher Education, 23(2), pp.157-172.

Lea, M. (2004) 'Academic literacies: a pedagogy for course design', Studies in Higher Education, 29(6), pp.739-756.

Lea, M. and Street, B. (2006) 'The Academic Literacies model: Theory and applications', Theory Into Practice, Fall, 45(4), pp.368-377.

Lillis, T. (2003) 'An "academic literacies" approach to student writing: Drawing on Bakhtin to move from critique to design', Language and Education, 17(3), pp.192-207.

Lillis, T., Harrington, K., Lea M. and Mitchell, S. (2016) Working with academic literacies: Case studies towards transformative practice. The WAC Clearinghouse, Parlour Press, Colorado.

Lillis, T. and Scott, M. (2007) 'Defining academic literacies research: issues of epistemology, ideology and strategy', Journal of Applied Linguistics. Available at: https://doi.org/10.1558/japl.v4i1.5 (Accessed: 5 May 2012).

Maldoni, A. and Lear, E. (2016) 'A decade of embedding: Where are we now?', Journal of University Teaching and Learning Practice, 13(3). Available at: http://ro.uow.edu.au/jutlp/vol13/iss3/2 (Accessed: 5 June 2018).

McWilliams, R. and Allan, Q. (2014) 'Embedding Academic Literacy Skills: Towards a Best Practice Model', Journal of University Teaching and Learning Practice, 11(3). Available at: http://ro.uow.edu.au/jutlp/vol11/iss3/8 (Accessed: 4 May 2016).

Minogue L., Murphy, C. and Salmons, K. (2018) 'Embedding learning development: a model for collaborative practice', Journal of Learning Development in Higher Education, Issue 13, April. Available at: http://journal.aldinhe.ac.uk/index.php/jldhe/article/view/443 (Accessed: 3 June 2019). 
Moore, T. and Hough, B. (2005) 'The perils of skills: Towards a model of integrating graduate attributes into the discipline', in Milnes, S. (ed.) Critiquing and reflecting: LAS profession and practice. Proceedings of the Language and Academic Skills in Higher Education Conference, 24-25 November. Canberra: The Australian National University. Available at:

http://www.aall.org.au/sites/default/files/las2005/Moore Hough.pdf (Accessed: 1 May 2016).

Morgan, H. and Houghton, A. (2011) 'Inclusive curriculum design in higher education: Considerations for effective practice across and within subject areas', Higher Education Academy, York, UK. Available at: https://www.heacademy.ac.uk/resources/detail/inclusion/Disability/Inclusive curricul um design in higher education (Accessed: 22 October 2015).

Murray, N. and Nallaya, S. (2016) 'Embedding academic literacies in university program curricula: a case study', Studies in Higher education, 41(7), pp.1296-1312. Available at: http://dx.doi.org/10.1080/03075079.2014.981150 (Accessed: 2 May 2019).

Norton, A. (2016) Mapping Australian higher education 2016, Grattan Institute Report. Available at: https://grattan.edu.au/report/mapping-australian-higher-education2016/ (Accessed: 1 June 2019).

Priest, A. (2009) 'I have understanding as well as you: Supporting the language and learning needs of students from low socio-economic status background', Journal of Academic Language and Learning, 3(2), A1-A12. Available at: http://journal.aall.org.au/index.php/jall/article/view/95/69 (Accessed: 2 February 2016).

Thies, L. (2012). 'Increasing student participation and success: Collaborating to embed academic literacies into the curriculum', Journal of Academic Language and Learning, 6(1), A15-A32. Available at: http://journal.aall.org.au/index.php/jall/article/view/127 (Accessed: 6 February 2012). 
Thies, L., Rosario, V., Goldingay, S., Nipperess, S., Coldwell-Neilson, J. and Shang, G. (2013a) 'Embedding academic literacies: the challenges of measuring success', AALL Conference, Melbourne, November.

Thies, L. Rosario, V. Goldingay, S. Wishart, L. (2013b) 'How reflecting collaborativley helps us support academic literacies development in two disciplines', AALL Conference, Melbourne, November.

Thies, L. Wallis, A. Turner, A. Wishart, L. (2014) 'Embedded academic literacies curricula: the challenges of measuring success', Journal of Academic Language and Learning, 8(2), A43-A59. Available at: http://journal.aall.org.au/index.php/jall/article/view/301 (Accessed: 24 May 2014).

Thies, L. (2016) 'Building staff capacity through reflecting on collaborative development of embedded academic literacies curricula', Journal of University Teaching and Learning Practice, 13(5) [Online]. Available at: https://ro.uow.edu.au/jutlp/vol13/iss5/19/ (Accessed: 22 December 2016).

Varghese, N. V. (2013) 'Globalization and higher education: Changing trends in cross border education', Analytical Reports in International Education, 5(1), pp.7-20.

Willison, J., Le Lievre, K. and Lee, I. (2010) 'Making research skill development explicit in coursework, Final Report', Australian Government Department of Education Employment and Workplace Relations: Australian Learning and Teaching Counsel.

Willison, J. and O'Regan, K. (2007) 'Commonly known, commonly not known; a framework for students becoming researchers', Higher Education Research and Development, 26(4), pp.393-409.

Wingate, U. (2006) 'Doing Away with Study Skills', Teaching in Higher Education, 11(4), pp.457-469.

Wingate, U. and Tribble C. (2012) 'The best of both worlds? Towards an English for Academic Purposes/Academic Literacies writing pedagogy', Society for Research 
into Higher Education. Available at: https://doi.org/10.1080/03075079.2010.525630 (Accessed: 1 May 2016).

Young, J. (2004) 'Becoming different: Accessing university from a low socio-economic community barriers and motivators', Systemic Practice and Action Research, 17(5), pp.425-469.

\section{Author details}

Linda Carol Thies is a Language and Learning Adviser at the Warrnambool campus of Deakin University. She is particularly interested in the development of students' academic literacies through an inclusive approach to curriculum development. Email: linda.thies@deakin.edu.au.

Viola Rosario remains interested in collaborative curriculum design and online development to support learning, though she has now retired from her role as a Language and Learning Adviser at the Burwood campus of Deakin University. Email: Viola.Rosario.LLA@gmail.com. 